\title{
Primary Separation of Antioxidants (Unsaponifiables) the Wet Biomass Microalgae Chlamydomonas sp. and Production of the Biodiesel
}

\author{
Gisel Chenard Díaz', Yordanka Reyes Cruz', Mariana Monteiro Fortes', \\ Carolina Vieira Viegas ${ }^{1}$, René González Carliz ${ }^{1}$, Nelson C. Furtado², \\ Donato A. Gomes Aranda1 \\ ${ }^{1}$ Greentec Laboratory, School of Chemistry, Federal University of Rio de Janeiro, Rio de Janeiro, Brazil
${ }^{2}$ Brazilian Center for Physical Researches, Rio de Janeiro, Brazil
Email: gisemarina@yahoo.es
}

Received 13 August 2014; revised 10 September 2014; accepted 25 September 2014

Copyright (C) 2014 by authors and Scientific Research Publishing Inc.

This work is licensed under the Creative Commons Attribution International License (CC BY).

http://creativecommons.org/licenses/by/4.0/

c) (i) Open Access

\section{Abstract}

This work studies the saponification which directs the wet biomass of algae Chlamydomonas sp. like a previous stage to production of biodiesel. This stage allows the obtainment of fatty acids to produce biodiesel, instead of the gross lipid fraction. In addition of the fatty acids, utilizing the same process one can also obtain the fraction unsaponifiable, these are soluble in apolar solvents and contain mainly carotenoids that can take action as antioxidants and photoprotectors, as they reduce the oxidation of unsaturated fatty acids. The saponification direct and extraction of fatty acids from biomass is faster and reduces the time and cost of operation. The separation of unsaponifiable matter from the biomass humid of microalgae Chlamydomonas sp., was held according to the method AOCS (Ca 6a-40), using extraction Liquid-liquid with hexane as solvent. Subsequently, phase hydroalcoholic or from soap, containing fatty acids, was acidified by addition of $\mathrm{H}_{2} \mathrm{SO}_{4}$ and the fatty acids were recovered by the addition of hexane. After acidulation of the soap, necessary for obtaining of the fatty acids was performed the stage of esterification for obtaining of biodiesel. The operating conditions were: molar ratio fatty acid:methanol $(1: 10)$, as catalyst $8 \%$ $\mathrm{H}_{2} \mathrm{SO}_{4}$ calculated in relation to the mass of fatty acid, $200^{\circ} \mathrm{C}$ and reaction time of 90 minutes. The content of methyl esters was $\mathbf{9 6 . 8 \%}$ determined by gas chromatography according to standard EN14103. The quality of biodiesel produced from wet biomass of Chlamydomonas sp. is according to the specification established by standard EN 14214 and RANP No. 14. For the identification of the composition the unsaponifiable fraction was used the method of High Performance Liquid 
Chromatography (HPLC). The composition of the material unsaponifiable found was of: Carotenoids total $(0.76 \%)$; Lutein $(0.45 \%)$; Zeaxanthin $(0.07 \%)$; $\alpha$-carotene $(0.05 \%)$; $\beta$-carotene $(0.11 \%)$; $13 \operatorname{cis} \beta$-carotene $(0.05 \%)$ and 9 -cis $\beta$-carotene $(0.03 \%)$.

\title{
Keywords
}

\author{
Biodiesel, Unsaponifiables, Esterification
}

\section{Introduction}

The use of microalgae as a feedstock for biodiesel represents a viable alternative, providing a gain energy, environmental benefits and production capacity in large quantities without reduction for goods alimentary [1]. Microalgae are organisms with large capacity of fix carbon dioxide and accumulate lipids, so that approximately half of the dry weight of their biomass is carbon, which means that $1 \mathrm{~kg}$ of algal biomass fixed $1.6-1.8 \mathrm{~kg} \mathrm{CO}$, and can regularly produce a lipid content from $50 \%$ to $60 \%$ by weight dry the biomass [2] [3].

Currently, the production of biodiesel from microalgae is too costly to compete with oil, so that the current challenges are associated with the isolation and selection of promising species of high accumulation of lipid content; a strategy of biorefinery producing, by improving the potential of microalgae through of genetic engineering and metabolic and advances in engineering of cultivation systems; to the development of technologies the harvest and processing which can make it feasible to commercial implementation of biofuel based on algae [4].

In this context to obtain the biodiesel by esterification of fatty acids of the wet biomass from the microalgae Chlamydomonas sp. was performed a study detailed to increase the extraction and purification of fatty acids from wet biomass. The extraction of these fatty acids was performed by a method in three stages: direct saponification of wet biomass, followed by extraction the unsaponifiables (antioxidants) and finally, acidulation of soap required to obtain fatty acids. In this study, hexane was used as solvent.

Additionally beyond of the extraction of fatty acids of the biomass, using the same procedure can also be obtained the unsaponifiable fraction, which are soluble in nonpolar solvents and contain mainly carotenoids which can act as antioxidants and photoprotectors because they reduce the oxidation of fatty acids unsaturated. Various researchers have concentrated efforts in assessing the antioxidant capacity of carotenoids from microalgae, for industrial applications not only in industry of food but especially for pharmaceuticals and cosmetics due to the high added value of these compounds [5]. According to recent studies [6], the pigments derived from microalgae showed a significant demand on the world market. The main microalgae that are sources of carotenoids are: Chlorella, Chlamydomonas sp., Dunaliella, Muriellopsis and Haematococcus sp., all belonging to the family Chlorophyceae [7].

The results showed the best performance in the process of obtaining biodiesel in the operating conditions: molar ratio fatty acid:methanol $(1: 10)$ as catalyst $8 \% \mathrm{H}_{2} \mathrm{SO}_{4}$ calculated in relation to the mass of fatty acid, $200^{\circ} \mathrm{C}$ and reaction time of 90 minutes.

The biodiesel produced from the wet biomass of Chlamydomonas sp. using the proposed methodology, complies with the specification for content of methyl esters established by standard EN 14214 and RANP No. 14. The identification of the composition of unsaponifiable fraction was utilized the method of High Performance Liquid Chromatography (HPLC).

\section{Materials and Methods}

\subsection{Materials}

Was utilized as raw material the wet biomass from the microalgae Chlamydomonas sp. (Figure 1), provided by the Research Center of Petrobras-CENPES, cultivated in the pilot unit of the Federal University of Rio Grande do Norte-UFRN in Natal using cultivator openwork type "Raceway ponds". The microalgal biomass was concentrated by flocculation followed by centrifugation. The humidity content of the biomass resulting was $73.79 \%$ determined on Balance of humidity Metler the temperature of $110^{\circ} \mathrm{C}$ for $90 \mathrm{~min}$. 


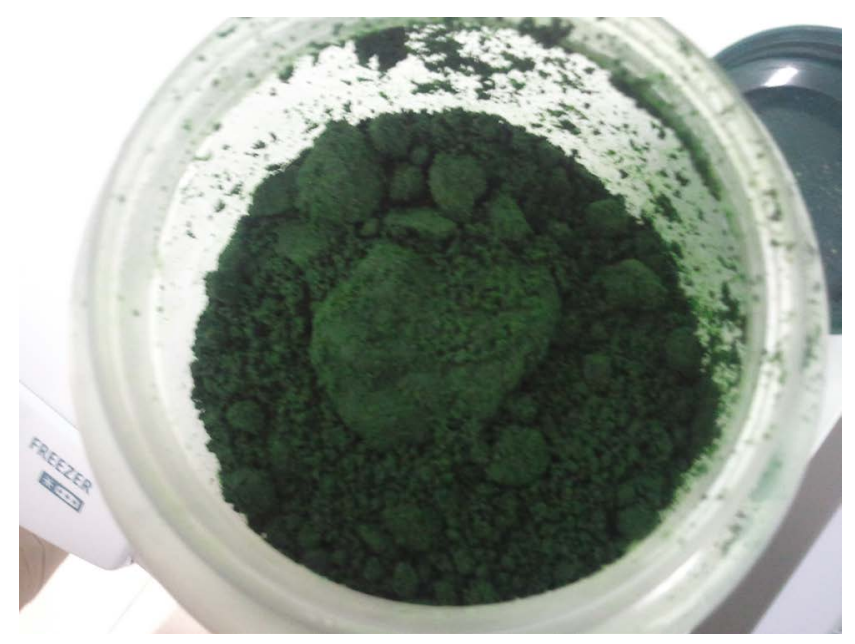

Figure 1. Biomass humid of microalgae Chlamydomonas sp.

\subsection{Characterization of the Biomass}

\subsubsection{Lipid Content}

The lipid content in biomass of microalgae Chlamydomonas sp. was determined following the method of Bligh and Dyer (1959) modified for the extraction of lipids [8].

The biomass used for extraction generated of the microalgae cultivation should be centrifuged at $8000 \mathrm{rpm}$ during $10 \mathrm{~min}$, washed twice with distilled water for be utilized. In the case of humid biomass, the lipids should be extracted after centrifugation, not being adequate storing the biomass, and determined the humidity present in the sample. The lipid extraction is done in two steps, at the first the sample is digested with hydrochloric acid to break through the wall cellular and at the second the lipids are extracted with the mixture of solvents.

In the first step based in the digestion of the sample with hydrochloric acid, was weighed $400 \mathrm{mg}$ of the sample directly in flask of extraction of Mojonnier $\left(m_{2}\right)$. Were added $5 \mathrm{~mL}$ of $8 \mathrm{M}$ hydrochloric acid solution and agitated to promote the dispersion of the material. Then the sample was heated in a water bath at $80^{\circ} \mathrm{C}$ for 1 hour to complete digestion of the cells. Posteriorly leave the flask to rest for 10 minutes at $25^{\circ} \mathrm{C}$ and centrifuged at $2000 \mathrm{rpm}$ for 15 minutes to separate the biomass and the acid residue. After digestion remove the residual acid and continue with the flask which contains the biomass to step the extraction of lipids.

In the second step were added to the flask Mojonnier the mixture of solvents, methanol, chloroform and water in the proportions (4:4:3.6), stirred for 10 minutes and centrifuged at $2000 \mathrm{rpm}$ for 15 minutes. After centrifugation were obtained 3 phases containing off the lower phase where the lipids are dissolved and chloroform (which we must recover) the middle phase containing biomass extracted and the upper phase composed of water and methanol.

Pour the ethereal phase (inferior) to the beaker previously weighed $\left(m_{1}\right)$ and repackage it in thermostatic bath at $65^{\circ} \mathrm{C}$ until complete evaporation of the solvent. In the phases remaining in the flask Mojonnier (biomass, methanol, water) do re-extraction of lipids who are still in biomass by adding $4 \mathrm{~mL}$ of $10 \%$ solution $\mathrm{v} / \mathrm{v}$ methanol in chloroform, shake and centrifuge at 2000 rpm for 15 minutes. This step is essential for migration of lipids withheld in the residue of microalgae for the solvent. Repeat the procedure for re-extraction one more time and remove off the lower phase where are lipids and join with the first extract (ethereal phase). Finally leave the beaker in a water bath at $65^{\circ} \mathrm{C}$, for the solvent evaporation. After removal of the solvents by evaporation, put the beaker in oven at $102^{\circ} \mathrm{C} \pm 2^{\circ} \mathrm{C}$ for 1 hour. Cool down in desiccator and weigh. Repeat drying and weighing until constant mass $\left(m_{3}\right)$. The content of lipids $(T L)$ as determined in triplicate is calculated by the Equation (1).

$$
T L=100 \times\left(m_{3}-m_{1}\right) / m_{2}
$$

\subsubsection{Lipid Profile of Microalgal Biomass}

To perform analysis of lipid profile the sample extracted in item 2.2.1 was submitted to reaction the saponification/methanolysis according to the methodology described next: Were used $300 \mathrm{mg}$ lipid sample. Then held sa- 
ponification with $1 \mathrm{~mL}$ of saturated solution of $\mathrm{KOH}-\mathrm{CH}_{3} \mathrm{OH}$ (alcoholic potash) to $75^{\circ} \mathrm{C}$ per 10 minutes in water bath. After the sample was subjected to methanolysis using $2 \mathrm{~mL}$ methanol with $5 \% \mathrm{HCl}$ at $75^{\circ} \mathrm{C}$ for 10 minutes in water bath. This step was performed in a closed bottle to prevent evaporation. Then, a phase containing the fatty acid was separated by adding $2 \mathrm{~mL}$ of distilled water and $2 \mathrm{~mL}$ of hexane. The top hexane phase was collected and transferred to a glass bottle, then placed in oven at $60^{\circ} \mathrm{C}$ for solvent evaporation and concentration of the sample [9].

After methanolysis be determined for the lipid profile by comparison with standard sample and determined by integrated areas for each peak by gas chromatography. It was necessary to dilute the sample in heptane at a ratio of 0.05:1 (w/w). Then $1 \mu \mathrm{L}$ of this sample was injected into the chromatograph Shimadzu, model GC-2010 with injector split/splitless, flame ionization detector (FID), Carbowax column $(30 \mathrm{~m} \times 0.32 \mathrm{~mm} \times 0.25 \mu \mathrm{m})$ brand Quadrex, with the following conditions: $200^{\circ} \mathrm{C}$ isothermal, injector: $250^{\circ} \mathrm{C}$, Detector: $250^{\circ} \mathrm{C}$, Pressure of the carrier stream: $1.9 \mathrm{~mL} / \mathrm{min}$. The analyzes were performed for $30 \mathrm{~min}$.

\subsection{Separation of Unsaponifiable Phase (Antioxidants) and Biodiesel Production}

\subsubsection{Stage 01: Saponification Reaction}

For the separation of unsaponifiable phase was held the saponification of three samples of wet biomass with 5 , 10 and $150 \mathrm{~g}$, according to the AOCS method (Ca 6a-40). Proceeded to the saponification of wet biomass of Clamydomonas sp. by the addition of 25, 100 and $2250 \mathrm{~mL}$ of hydroalcoholic solution of potassium hydroxide at $35 \%$. Each reaction was performed in a balloon $2 \mathrm{~L}$ at a temperature of $80^{\circ} \mathrm{C}$ for $1 \mathrm{~h}$. Posteriorly the sample is vacuum filtered to remove the solid waste of the biomass. The permeate is placed in a separatory funnel for separation of unsaponifiable phase, using liquid-liquid extraction with three volumes of hexane as the solvent. The ethereal phase containing the unsaponifiable was conducted at three washes with deionized water for the removal of residues sodium hydroxide. The solvent was recovered in evaporator coupled rotary with a balloon previously dried and weighed. The solid residue was dried in an oven to constant weight. The percentage of unsaponifiables was calculated in relation the initial mass of biomass. For identification of the composition of unsaponifiable fraction the solid residue was re-dissolved in heptane and analyzed using the method of High Performance Liquid Chromatography (HPLC) [10].

\subsubsection{Stage 02: Acidulation of Soap}

The aqueous phase (soap phase) resulting of each of the processed samples, was added the stoichiometric molar amount of $\mathrm{H}_{2} \mathrm{SO}_{4}$ needed to obtain of fatty acids. The reactants were placed under magnetic stirring at a temperature of $80^{\circ} \mathrm{C}$. After 1 hour reaction time the sample is transferred to a separatory funnel. The sample is washed with distilled water to eliminate the residual sulfuric acid and salt $\mathrm{K}_{2} \mathrm{SO}_{4}$. The fatty acids were separated with three washes with hexane. The hexane is recovered and fatty acids weighed gravimetrically.

\subsubsection{Stage 03: Esterification of Fatty Acids}

After obtaining the fatty acids was held the stage of esterification. The operating conditions were: molar ratio fatty acid:methanol $(1: 10)$ as catalyst $8 \% \mathrm{H}_{2} \mathrm{SO}_{4}$ calculated in relation to the mass of fatty acid, $200^{\circ} \mathrm{C}$ and reaction time of 90 minutes. At the end of the reaction, the biodiesel was washed with warm distilled water up to a $\mathrm{pH} \geq 7$. Soon after slowly heated to a temperature of $110^{\circ} \mathrm{C}$ to remove by evaporation any trace of water.

The content of the methyl esters of fatty acids was determined according to the standard EN14103, using a gas chromatograph, Shimadzu GC2014 coupled to a flame ionization detector (FID), injector of type split/splitless and a capillary column DB-23 (30 m $\times 0.25 \mathrm{~mm} \times 0.25 \mu \mathrm{m})$ mark Agilent, to the following conditions: injector: $250^{\circ} \mathrm{C}$, flow 50:1; Arrastre gas: Hydrogen; Pressure of the carrier stream: $1 \mathrm{~mL} / \mathrm{min}$; Detector: $280^{\circ} \mathrm{C}$, the auxiliary gas (make-up) was $\mathrm{N}_{2}(30 \mathrm{~mL} / \mathrm{min}), \mathrm{H}_{2}(30 \mathrm{~mL} / \mathrm{min})$ and synthetic air (30 mL/min). Programming of the oven temperature: $60^{\circ} \mathrm{C}$ for 2 minutes, $60^{\circ} \mathrm{C}$ to $200^{\circ} \mathrm{C}$ (gradient of $10^{\circ} \mathrm{C}$ per minute); $200^{\circ} \mathrm{C}$ to $240^{\circ} \mathrm{C}$ (gradient of $5^{\circ} \mathrm{C}$ per min) and isothermal for 15 minutes. Analyses were performed for 30 min.

The identification of methyl esters of fatty acids was performed by comparison of retention times of the sample constituents with the respective standard fatty acid methyl esters from Sigma (C4:0 - C24:0) and the quantification $(\% \mathrm{~m} / \mathrm{m})$ was performed relative to an internal standard, methyl nonadecanoate (C19:0), through software GCsolution version 2.2 (Shimadzu). 


\section{Results}

\subsection{Characterization of Biomass}

The microalgae Chlamydomona sp. is found within of the classification Chlorophyceae of the green algae, within the group of Chlamydomonadais, where it includes all those who are unicellular photosynthetic and flagellated [11] [12]. The typical composition of the biomass Chlamydomona sp. is: lipid content of 21\% - 25\%, protein $48 \%$ and carbohydrates $17 \%$ relative to the dry weight of the biomass [13]-[17]. The result of lipid content in the lineage under study presents itself in Table 1.

The percentage total lipid was $22.5 \%$. It was found an insignificant difference between the values obtained from the three replicates (C1, C2 and C3). The obtained value corresponds with the percentage of lipids reported in the literature for microalgae of this genus [14]-[16]. Is observed in several studies greater efficacy of extracting by the modified method of Bligh and Dyer (1959), by the use of hydrochloric acid for the disruption of cells, thus enabling the release of oil [8] [14].

The lipid profile of microalgal biomass Chlamydomona sp. obtained through analysis of esters by gas chromatography is presented in Table 2 and Figure 2. According to these results, the species studied showed the following distribution of saturated fatty acids (SAFA) and unsaturated (MUFA and PUFA): content of SAFA > PUFA > MUFA. It is observed that the highest values refer to SAFAs with emphasis on the C16:0 (palmitic acid). In relation to the PUFA was observed high content of C18:3 (linolenic acid). The second PUFAs higher content of was C18:2 (linoleic). Regarding to MUFA stands out C18:1 (oleic acid) and C16:1 (palmitoleic acid).

The microalgal biomass of Chlamydomona sp. showed high content of SAFA principally of C16:0 (palmitic acid). With contents near $40 \%$ being this a characteristic similar to the tallow and palm oils, which are rich in saturated fatty acids. The C18:3 (linolenic acid) was also identified in high amounts (23.97\%) and the C18:2 (linoleic acid) with (10.77\%), they appear in higher contents in soybean. On the other hand, the specie showed $17.95 \%$ of MUFAs totals, mainly represented by C18:1 (oleic acid) with $11.43 \%$, the second present in high contents in sebum and in olive oil mostly.

These results were compatible with those found in previous works, where the palmitic acid was determined as a predominant in most species of microalgae grown in fresh water [18]-[20]. A microalga Scenedesmus obliquus

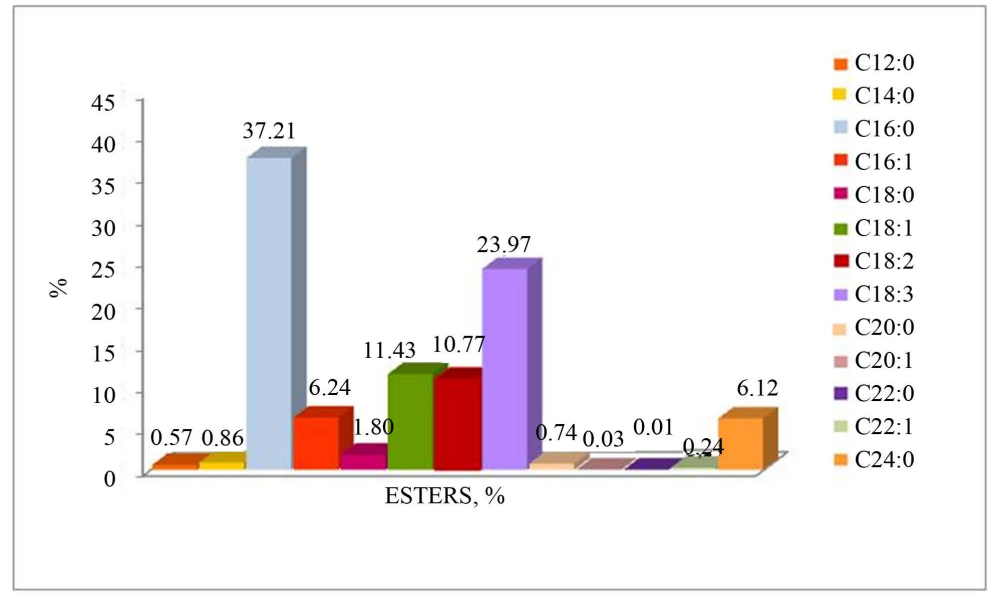

Figure 2. Lipid Profile of biomass Chlamydomona sp.

Table 1. Lipid content of microalgae Chlamydomona sp.

\begin{tabular}{ccc}
\hline Chlamydomona sp. & Total Lipids (\%) \\
\hline C1 & 22.28 \\
C2 & 21.64 & 22.23 \\
C3 & $22.05 \pm 0.70$ \\
\hline
\end{tabular}


Table 2. Lipid profile of microalgae Chlamydomona sp.

\begin{tabular}{ccc}
\hline FATTY ACID & $\begin{array}{c}\text { Number of carbon atoms: } \\
\text { Number of unsaturations }\end{array}$ & $\begin{array}{c}\text { COMPOSITION } \\
\text { (\% Area normalized) }\end{array}$ \\
\hline Lauric & C12:0 & 0.57 \\
Myristic & C14:0 & 0.86 \\
Palmitic & C16:0 & 37.21 \\
Palmitoleic & C16:1 & 6.24 \\
Stearic & C18:0 & 1.80 \\
Oleic & C18:1 & 11.43 \\
Linoleic $(\infty 6)$ & C18:2 & 10.77 \\
Linolenic $(\infty 3)$ & C18:3 & 23.97 \\
Arachidic & C20:0 & 0.74 \\
Gadoleic & C20:1 & 0.03 \\
Behenic & C22:0 & 0.01 \\
Erucic & C22:1 & 0.24 \\
Lignoceric & C24:0 & 6.12 \\
\hline
\end{tabular}

showed a concentration of palmitic acid (C16:0) between 35.86\% and 43.06\% [21]. This fact does not preclude the possible use of this microalgae as raw material for biodiesel production. That amount of saturated fatty acids in microalgae was also observed in [9] when he studied the lipid profile of the microalgae Chlorella vulgaris, Scenedesmus sp. and Botryococcus braunni. In this study the researchers obtained 36.3\% palmitic acid for Scenedesmus sp.

\subsection{Separation of Unsaponifiable Phase (Antioxidants) and Biodiesel Production}

\subsubsection{Stage 01: Saponification Reaction}

From the three reactions of saponification performed was separate the unsaponifiable material, shown in Figure 3. The quantity of unsaponifiable materials extracted in each reaction is presented in Table 3.

Was observed good separation of phases in the three reactions performed. The results show that the increase of 5 (R1) to 10 (R2), times of hydroalcoholic solution in relation to processed biomass almost doubled the content of unsaponifiable materials extracted. However, with increasing of the relation 10 (R2) to 15 (R3) times has not been observed differentiates significant in content in unsaponifiable material.

It was found that the composition and the proportion of minority components in the unsaponifiable phase varies depending of the lineage and cultivation conditions. The composition of the unsaponifiable material found of three reactions (R1, R2, R3) was of: Total carotenoids (4921, 7344, 7589 ppm); Lutein (2945, 4318, 4454 ppm); Zeaxanthin (515, 695, 713 ppm); $\alpha$-carotene (302, 451, 461 ppm); $\beta$-carotene (721, 1077, 1108 ppm); 13 $\operatorname{cis} \beta$-carotene (251, 524, $537 \mathrm{ppm})$ and 9-cis $\beta$-carotene (187, 279, $288 \mathrm{ppm})$. These values lie within the ranges reported in the literature [22]-[24].

It was also determined the residual potassium, considering that these antioxidants for use in the food industry must be met specifications very restricted. The concentration of Potassium $\left(\mathrm{K}^{+}\right)$in the samples of unsaponifiable materials obtained in the reactions R1, R2 and R3 were 20.30 ppm (0.00203\%); 25.10 ppm (0.00251\%); 45.28 ppm $(0.004528 \%)$ respectively. These low values ensures the use of antioxidants extracted in the food industry because are within the Acceptable Daily Intake (IDA- $0.7 \mathrm{mg} / \mathrm{kg}$ body weight) [25].

\subsubsection{Stage 02: Acidulation of Soap}

With the objective of producing biodiesel from the lipids present in microalgal biomass of Chlamydomona sp., after extraction of antioxidants were performed acidification reactions from soap formed in each the saponification reaction. In the acidulation the following amounts of fatty acids were obtained: RA1 $0.08 \mathrm{~g}$ fatty acids 


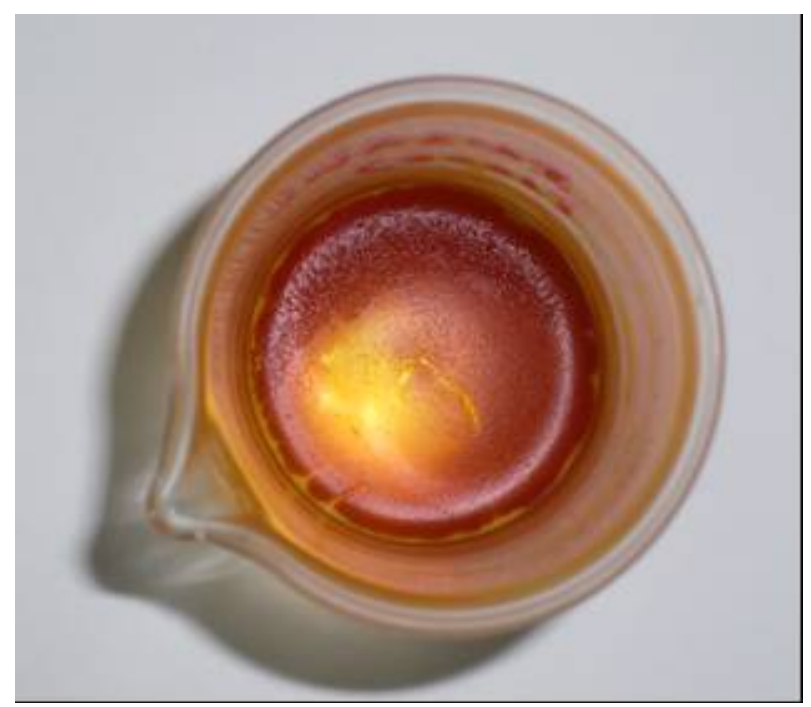

Figure 3. Unsaponifiable material-antioxidants extracted from wet biomass the microalgae Chlamydomonas sp.

Table 3. Unsaponifiables the microalgae Chlamydomona sp.

\begin{tabular}{ccccc}
\hline & \multicolumn{3}{c}{ Saponificação } & \\
\cline { 2 - 5 } Reaction & $\begin{array}{c}\text { Wet } \\
\text { Biomass (g) }\end{array}$ & $\begin{array}{c}\text { Dry } \\
\text { Biomass (g) }\end{array}$ & $\begin{array}{c}\text { Unsaponifiable } \\
\text { (g) }\end{array}$ & \% in Relation to Dry Biomass \\
R1 & 5 & 1.3105 & 0.0145 & 1.1064 \\
R2 & 10 & 2.6210 & 0.0523 & 1.9954 \\
R3 & 150 & 39.5771 & 0.8224 & 2.0779 \\
\hline
\end{tabular}

(6.1045\% of dry biomass); RA2 $0.17 \mathrm{~g}$ fatty acids (6.5223\% of dry biomass); RA3 $3.12 \mathrm{~g}$ fatty acids (7.8833\% of dry biomass). Considering that the content of total lipids determined initially on this biomass Chlamydomona sp. was of $22.05 \%$ is possible to say, from the results obtained that only between $6 \%-7 \%$ of these lipids are convertible to biodiesel.

\subsubsection{Stage 03: Esterification of Fatty Acids}

In Table 4, we show the results obtained in the three esterification reactions of fatty acids of Chlamydomona sp. well as the content of FAME (fatty acid methyl esters) more as determined by gas chromatography (GC-FID).

Biodiesel produced from the wet biomass of Chlamydomonas sp. using the proposed methodology, meets the specifications for content of methyl esters established by EN 14214 and RANP No. 14. The content of methyl esters (\%) in average of the three esterification reactions was $96.5 \%$.

Table 5 presents the results of the composition profile of methyl esters of Chlamydomona sp. of three samples of biodiesel determined by gas chromatography.

In the composition of biodiesel continued to be the predominant saturated methyl esters such as palmitate (35.46\% to $45.43 \%$ ), fact related with predominance of the content of esters derived from palmitic acid. Aspect that could give greater oxidative stability of biodiesel, but it could affect indices like the point of Cold filter plugging. In relation to the polyunsaturated methyl esters it was observed a high content of linolenate $(24.40 \%$ to $29.40 \%)$ and in relation to monounsaturated methyl esters we highlight the content of oleate $(12.27 \%$ to 15.84\%). As has been amply discussed, the palmitic acid, oleic acid and linolenic acid were the dominant constituents in the lipid composition of the microalgal biomass studied. These fatty acids medium-chain (C16 and C18) are considered ideal for the production of high quality biodiesel, and constitute the parameter more direct and precise to evaluate the potential of microalgae as raw material for biodiesel production, since not all compounds solubles in organic solvents used in extraction can be converted into biodiesel. 
Table 4. Esterification of fatty acids the microalgae Chlamydomona sp.

\begin{tabular}{ccccc}
\hline \multirow{2}{*}{ Reactions } & \multicolumn{2}{c}{ Acidulation of Soap } & Biodiesel \\
\cline { 2 - 5 } & $\begin{array}{c}\text { Fatty } \\
\text { Acids (g) }\end{array}$ & \% in Relation to Dry Biomass & $\begin{array}{c}\text { Methyl } \\
\text { Esters (g) }\end{array}$ & Content of Methyl Esters (\%) \\
\hline RE1 & 0.08 & 6.1045 & 0.0778 & 96.0 \\
RE2 & 0.17 & 6.5223 & 0.1615 & 96.6 \\
RE3 & 3.12 & 7.8833 & 2.9952 & 96.8 \\
\hline
\end{tabular}

Table 5. Composition of methyl esters (\%) of Chlamydomona sp.

\begin{tabular}{|c|c|c|c|}
\hline \multirow{2}{*}{$\begin{array}{l}\text { FATTY ACID } \\
\text { ESTERIFIED }\end{array}$} & \multicolumn{3}{|c|}{$\begin{array}{l}\text { COMPOSITION } \\
\text { (\% area normalized) }\end{array}$} \\
\hline & RE1 & RE2 & RE3 \\
\hline Laurate & 0.04 & 0.09 & 0.40 \\
\hline Myristate & 0.68 & 0.75 & 0.53 \\
\hline Palmitate & 35.83 & 35.46 & 45.43 \\
\hline Palmitoleate & 11.37 & 12.96 & 1.82 \\
\hline Stearate & 2.46 & 2.19 & 0.82 \\
\hline Oleate & 12.27 & 12.45 & 15.84 \\
\hline Linoleate & 8.35 & 7.34 & 4.64 \\
\hline Linolenate & 24.40 & 24.65 & 29.40 \\
\hline Arachidate & 0.13 & 0.28 & 0.01 \\
\hline Gadoleato & 0.51 & 0.94 & 0.45 \\
\hline Behenate & 0.15 & 0.18 & 0.11 \\
\hline Erucate & 0.50 & 0.34 & 0.19 \\
\hline Lignocerate & 3.48 & 2.28 & 0.10 \\
\hline
\end{tabular}

\section{Conclusions}

The direct saponification of wet microalgal biomass for the production of fatty acids and subsequently obtaining biodiesel, presents itself as a process promising and fast reducing the operating time and cost, as well as allows valorize products such as antioxidant of carotenoid (unsaponifiable) high value added for industrial applications.

In the saponification of wet biomass, it was proved that a ratio of 10 times hydroalcoholic solution in relation for dry biomass would be sufficient for the extraction of unsaponifiable material.

The analysis of fatty acids presented in the microalga study showed a predominance of saturated fatty acids, considered ideal for the production of high quality biodiesel. The characteristics of biodiesel obtained from wet biomass of Chlamydomonas sp. using proposed technology are similar to those produced biodiesel of raw materials conventional according to the specification established by EN 14214 and RANP No. 14.

\section{References}

[1] Hill, J., Nelson, E., Tilman, D., Polasky, S. and Tiffany, D. (2006) Environmental, Economic, and Energetic Costs and Benefits of Biodiesel and Ethanol Biofuels. PNAS, 103, 11206-11210. http://dx.doi.org/10.1073/pnas.0604600103

[2] Sheehan, J., Dunahay, T., Benemann, J. and Roessler, P. (1998) A Look Back at the U.S. Department of Energy's Aquatic Species Program-Biodiesel from Algae. National Renewable Energy Laboratory, Report NREL/TP-580-24190.

[3] Patil, V., Tran, K.Q. and Giseirod, H.R. (2008) Towards Sustainable Production of Biofuels from Microalge. International Journal Molecular Sciences, 9, 1188-1195. http://dx.doi.org/10.3390/ijms9071188

[4] Griffiths, M.J. and Harrison, S.T.L. (2009) Lipid Productivity as a Key Characteristic for Choosing Algal Species for 
Biodiesel Production. Journal of Applied Phycology, 21, 493-507. http://dx.doi.org/10.1007/s10811-008-9392-7

[5] Spolaore, P., Joannis-Cassan, C., Duran, E. and Isambert, A. (2006) Commercial Applications of Microalgae. Journal of Bioscience and Bioengineering, 101, 87-96. http://dx.doi.org/10.1263/jbb.101.87

[6] Lorenz, R.T. and Cysewski, G.R. (2003) Commercial Potential for Haematococcus microalga as a Natural Source of Astaxanthin. Trends in Biotechnology, 18, 160-167. http://dx.doi.org/10.1016/S0167-7799(00)01433-5

[7] Pulz, O. (2004) Photobioreactors: Production Systems for Phototrophic Microorganisms. Applied Microbiology and Biotechnology, 57, 287-293.

[8] Bligh, G. and Dyer, W. (1959) A Rapid Method for Total Lipid Extraction and Purification. Canadian Journal of Biochemistry and Physiology, 37, 911-917. http://dx.doi.org/10.1139/059-099

[9] Yoo, C., Jun, S.Y. and Lee, J.Y. (2010) Selection of Microalgae for Lipid Production under High Levels Carbon Dioxide. Bioresource Technology, 101, S71-S74. http://dx.doi.org/10.1016/j.biortech.2009.03.030

[10] Pacheco, S. (2009) Preparo de padrões analíticos, estudo de estabilidade e parâmetros de validação para ensaio de carotenóides por cromatografia líquida. UFRRJ, Dissertação, Mestrado em Ciência e Tecnologia de Alimentos, Ciência dos Alimentos, Seropédica, 106 p.

[11] Tsigankov, A.A., Kosourov, S.N., Tolstygina, I.V., Ghirardi, M.L. and Seibert, M. (2006) Hidrogen Production by Sulfur-Deprived Chlamydomonas reinhardtii under Photoautotrophic Conditions. Internacional Journal of Hidrogen Energy, 31, 1574-1584.

[12] Mattox, K.R. and Stewart, K.D. (1984) Classification of the Green Algae: A Concept Based on Comparative Cytology. In: Irvine, D.E.G. and John, D., Eds., Systematics of the Green Algae, Academic Press, London, 41, 42, 57, 58.

[13] Becker, W. (2004) Microalgae in Human and Animal Nutrition. In: Richmond, A., Ed., Handbook of Microalgal Culture: Biotechnology and Applied Phycology, Blackwell Science, London, 566 p.

[14] Carolino, L. do R.V.C. (2011) Cultivo de microalgas unicelulares para determinação da produção lipídica e sequestro de carbono. ULisboa Faculdade de Ciências Departamento de Biologia Vegetal, Mestrado de Biologia Celular e Biotecnologia, 91.

[15] Chisti, Y. (2007) Biodiesel from Microalgae. Biotechnology Advances, 25, 294-306. http://dx.doi.org/10.1016/j.biotechadv.2007.02.001

[16] Gouveia, L. and Oliveira, A. (2009) Microalgae as Raw Materials for Biofuels Production. Journal of Industrial Microbiology and Biotechnology, 36, 269-274. http://dx.doi.org/10.1007/s10295-008-0495-6

[17] Deng, X., Li, Y. and Fei, X. (2009) Microalgae: A Promising Feedstock for Biodiesel. African Journal of Microbiology Research, 3, 1008-1014.

[18] Colla, L.M., Bertolini, T.E. and Costa, J.A. (2004) Fatty Acids Profile of Spirulina platensis Grown under Different Temperatures and Nitrogen Concentrations. Zeitschrift fur Naturforschung, 59, 55-59.

[19] Deshnium, P., Paithoonrangsarid, K. and Suphatrakul, A. (2000) Temperature-Independent and Dependent Expression of Desaturase Genes in Filamentous Cyanobacterium Spirulina platensis strain C1 (Arthrospira sp. PCC 9438). FEMS Microbiology Letters, 184, 207-213. http://dx.doi.org/10.1111/j.1574-6968.2000.tb09015.x

[20] Olguín, E., Galicia, S. and Angulo-Guerrero, O. (2001) The Effect of Low Light Flux and Nitrogen Deficiency on the Chemical Composition of Spirulina sp. (Arthrospira) Grown on Digested Pig Waste. Bioresource Technology, 77, 1924. http://dx.doi.org/10.1016/S0960-8524(00)00142-5

[21] Makulla, A. (2000) Fatty Acid Composition of Scenedesmus obliquus: Correlation to Dilution Rates. LimnologicaEcology and Management of Inland Waters, 30, 162-168. http://dx.doi.org/10.1016/S0075-9511(00)80011-0

[22] Eonseon, J., Polle, J.E.W., Kumlee, H., Hyun, S.M. and Chang, M. (2003) Xanthophylls in Microalgae: From Biosynthesis to Biotechnological Mass Production and Application. Journal of Microbiology and Biotechnology, 13, 165-174.

[23] Guerin, M., Huntley, M.E. and Olaizola, M. (2003) Haematococcus Astaxanthin: Application for Human Health and Nutrition. Trends in Biotechnology, 21, 210-216. http://dx.doi.org/10.1016/S0167-7799(03)00078-7

[24] Del-Campo, J.A., Garcia-Gonzalez, M. and Guerrero, M.G. (2007) Outdoor Cultivation of Microalgae for Carotenoid Production: Current State and Perspectives. Applied Microbiology and Biotechnology, 74, 1163-1174. http://dx.doi.org/10.1007/s00253-007-0844-9

[25] Brasil. Agência Nacional de Vigilância Sanitária. Resolução da Diretoria Colegiada-RDC No. 217, de 29 de julho de 2005. https://prosig.alvessilva.com.br/textos/5853.doc 
Scientific Research Publishing (SCIRP) is one of the largest Open Access journal publishers. It is currently publishing more than 200 open access, online, peer-reviewed journals covering a wide range of academic disciplines. SCIRP serves the worldwide academic communities and contributes to the progress and application of science with its publication.

Other selected journals from SCIRP are listed as below. Submit your manuscript to us via either submit@scirp.org or Online Submission Portal.
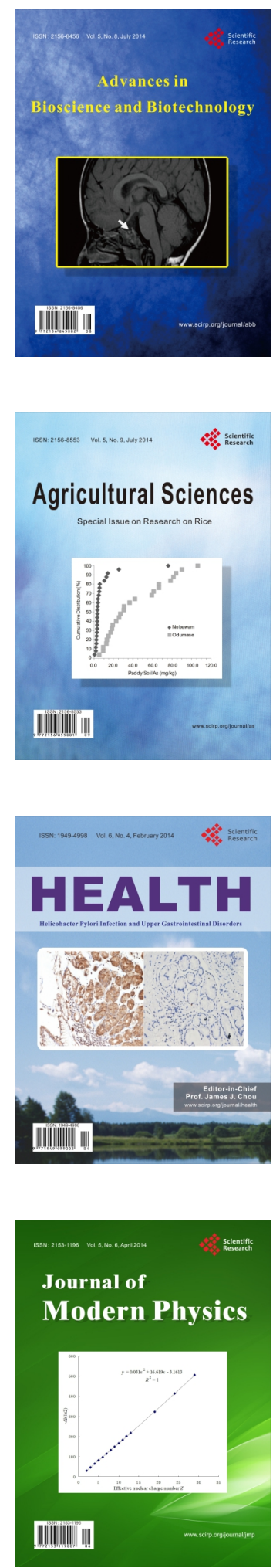
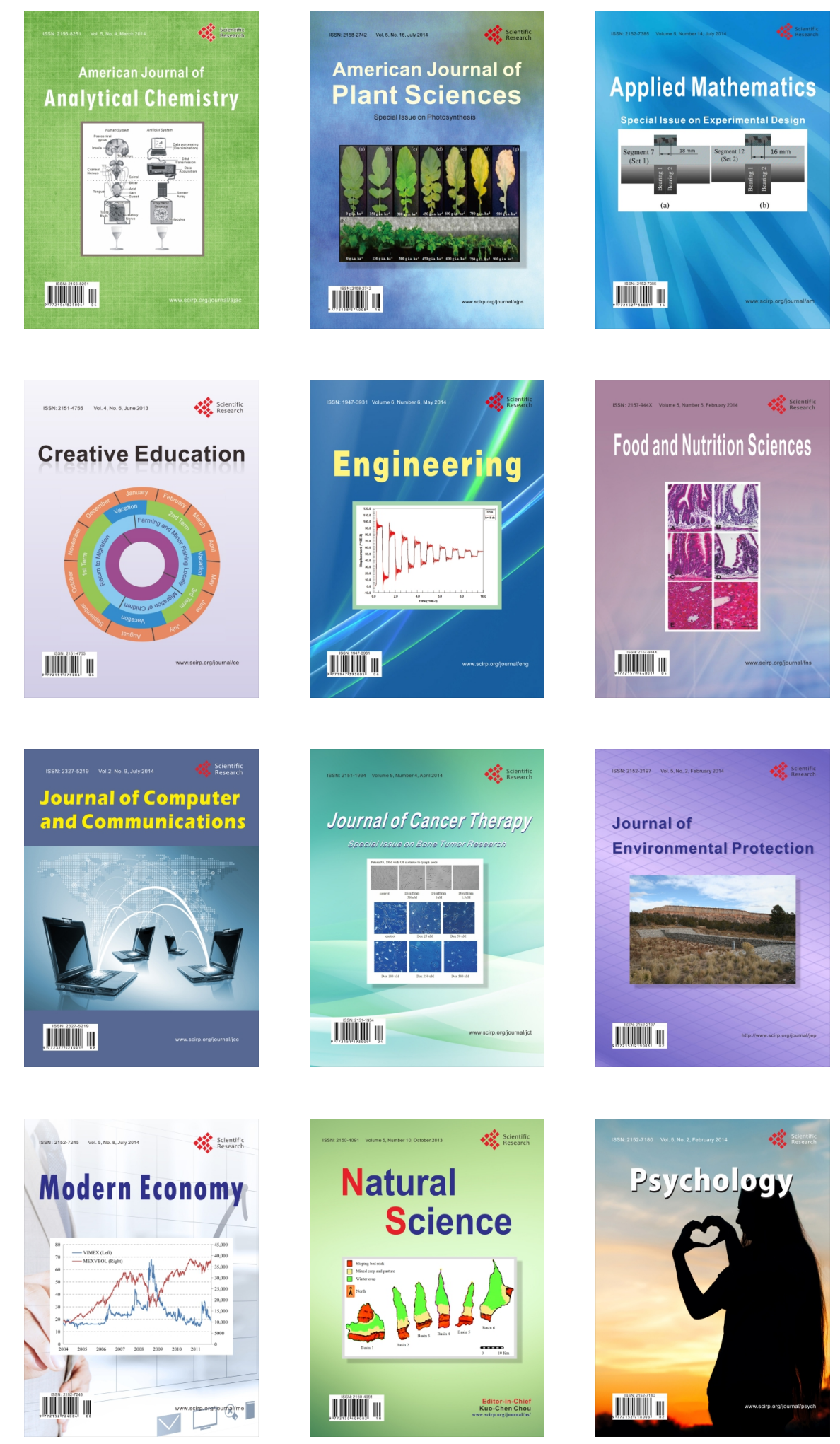